Artikel Penelitian

\title{
Gambaran Anemia Pada Kehamilan Di Bagian Obstetri Dan Ginekologi RSUP Dr. M. Djamil Padang Periode 1 Januari 2012 sampai 31 Desember 2012
}

\author{
Cut Mutiara Sabrina ${ }^{1}$, Joserizal Serudji ${ }^{2}$, Almurdi $^{3}$
}

\begin{abstract}
Abstrak
Anemia sampai saat ini masih menjadi masalah dunia, terjadi di negara berkembang maupun di negara maju. Anemia dapat terjadi pada semua usia, terutama perempuan hamil. Asia Tenggara memiliki prevalensi tertinggi dibanding dengan Afrika, Amerika, Eropa, Asia Pasifik, dan Mediterania Timur. Berdasarkan kriteria WHO, perempuan hamil didiagnosis menderita anemia jika memiliki kadar $\mathrm{Hb} \leq 11 \mathrm{~g} / \mathrm{dL}$. Tujuan penelitian ini adalah untuk mengetahui gambaran anemia pada kehamilan di bagian obstetrik dan ginekologi RSUP Dr. M. Djamil Padang dari periode tanggal 1 Januari 2012 sampai 31 Desember 2012. Penelitian ini merupakan studi deskriptif dengan menggunakan data rekam medik di RSUP Dr. M. Djamil Padang. Hasil penelitian memperlihatkan angka kejadian anemia pada kehamilan sebanyak 75 kasus $(2,2 \%)$ dari 3396 kehamilan. Derajat anemia pada kehamilan yang paling banyak ditemukan adalah derajat sedang, yaitu sebanyak 45 kasus $(60 \%)$, diikuti oleh derajat ringan sebanyak 20 kasus $(27 \%)$, dan derajat berat sebanyak 10 kasus (13\%). Anemia pada kehamilan lebih sering terjadi pada trimester ke-3 kehamilan, yaitu sebanyak 57 kasus (76\%). Mayoritas anemia pada kehamilan terjadi pada multigravida, yaitu sebanyak 50 kasus $(66,6 \%)$. Kasus anemia pada kehamilan terbanyak ditemukan pada paritas 1 ditemukan sebanyak 34 kasus (45,3\%). Mayoritas anemia pada kehamilan terjadi pada jarak kehamilan $>3$ tahun, yaitu sebanyak 25 kasus $(44,7 \%)$.
\end{abstract}

Kata kunci: anemia, kehamilan, hemoglobin

\begin{abstract}
Anemia is a global public health problem, affecting both developing and developed countries. It occurs at all stages of life cycle but is more prevalent in pregnant women. South-East Asia has the highest prevalence than Africa, America, Europe, Pasific Asia, and Eastern Mediterranean. WHO identifies anemia in pregnanct as a haemoglobin $(H b)<11 \mathrm{~g} / \mathrm{dl}$. The objective of this study was to describe the prevalence of anemia among pregnant women recorded in RSUP Dr. M. Djamil Padang from January $1^{\text {st }}$, 2012 to December $31^{\text {st }}, 2012$ using descriptive study design. The results showed 75 cases (2,2\%) from 3396 pregnancy were found during that period. Moderate anemia was the most common type found in this study, 45 cases (60\%), followed by mild type 20 cases (27\%), and severe type 10 cases (13\%). Most of patients were in their third trimester 57 cases (76\%).Majority, 50 cases (66,6\%) of anemia in pregnancy were multigravid. Anemia in pregnancy were found more frequent 34 cases $(45,3 \%)$ in women whose parity 1 , and child spacing $>3$ years, 25 cases $(44,7 \%)$.
\end{abstract}

Keywords: anemia, pregnancy, haemoglobin

Affiliasi penulis: 1. 1. Prodi Profesi Dokter FK Unand (Faklutas Kedokteran Universitas Andalas Padang) 2. Bagian Obstetri \& GInekologi FK Unand, 3. Bagian Patologi Klinik FK Unand.
Korespondensi: Cut Mutiara Sabrina, Email: rarararong@yahoo.com, telp: 081260105050 


\section{PENDAHULUAN}

Anemia adalah keadaan massa eritrosit dan/atau massa hemoglobin yang beredar tidak dapat memenuhi fungsinya untuk menyediakan oksigen bagi jaringan tubuh atau dapat juga disimpulkan sebagai penurunan kadar hemoglobin, hematokrit, atau hitung eritrosit di bawah normal. ${ }^{1}$ Seorang perempuan hamil didiagnosis mengalami anemia apabila memiliki kadar hemoglobin dibawah $11 \mathrm{~g} / \mathrm{dl}^{2}$

World Health Organization (WHO) memerkirakan sebanyak 1,62 milyar penduduk dunia mengalami anemia dan 56,4 juta dari penderita anemia tersebut merupakan perempuan hamil. WHO memperkirakan jumlah perempuan hamil yang menderita anemia di Asia Tenggara sebanyak 18,1 juta. Asia Tenggara memiliki prevalensi tertinggi dibanding dengan Afrika, Amerika, Eropa, Asia Pasifik, dan Mediterania Timur. ${ }^{2}$

Penyakit anemia di Indonesia merupakan masalah kesehatan dengan tingkat berat, terjadi pada lebih dari $40 \%$ dari populasi. ${ }^{2}$ Prevalensi anemia pada kehamilan di Indonesia dilaporkan sebanyak 24,5\%, sementara prevalensi anemia pada kehamilan di Solok dilaporkan sebesar 49,35 \%. ${ }^{3,4}$

Anemia dapat disebabkan oleh berbagai macam hal. Penyebab utama anemia pada kehamilan adalah defisiensi besi, kemudian diikuti oleh defisiensi folat $^{5}$. Diperkirakan sebanyak $50 \%$ anemia merupakan anemia defisiensi besi. Kehilangan darah yang banyak pada saat menstruasi, infeksi parasit seperti cacing tambang, infeksi oleh tuberkulosis dan malaria, serta kanker juga dapat menyebabkan anemia.

Pada minggu ke-6 hingga ke-8 kehamilan, terjadi peningkatan volume darah sebanyak $50 \%$, sementara peningkatan massa eritrosit hanya sebanyak $33 \%{ }^{6}$ Akibat ketidakseimbangan antara peningkatan volume darah dan massa eritrosit ini, menyebabkan terjadinya hemodilusi fisiologis yang akan menyebabkan terjadinya penurunan kadar hemoglobin dan hematokrit. ${ }^{7}$

Anemia pada kehamilan memberikan dampak buruk terhadap ibu dan janin. Perempuan hamil dengan anemia akan mengalami peningkatan risiko morbiditas dan mortalitas, terutama meningkatnya angka kematian jika terjadi hemoragia postpartum, sedangkan dampaknya pada janin akan meningkatkan risiko kelahiran prematur, berat badan lahir rendah, dan nilai Apgar yang rendah. ${ }^{8,9}$ Dampak buruk diatas dilaporkan juga oleh terjadi di Bolivia. ${ }^{10}$

Beberapa penelitian melaporkan bahwa anemia derajat ringan lebih sering terjadi. ${ }^{11,12}$ Beberapa penelitian melaporkan hasil yang berbeda, dimana dilaporkan bahwa derajat anemia pada kehamilan yang paling sering terjadi adalah anemia derajat sedang. ${ }^{13,14}$

Anemia pada kehamilan dilaporkan lebih sering terjadi pada trimester ke-2 kehamilan, sementara beberapa hasil penelitian melaporkan anemia pada kehamilan lebih sering terjadi pada trimester ke-3 kehamilan. $^{15,16}$ Anemia pada kehamilan dilaporkan lebih sering terjadi pada multigravida, sementara penelitian lain melaporkan anemia lebih sering terjadi pada grandemultigravida. ${ }^{16,17}$

Tidak didapatkannya data mengenai angka kejadian anemia pada kehamilan di bagian Obstetri dan Ginekologi RSUP M. Djamil Padang, menjadi alasan untuk melakukan penelitian ini.

\section{METODE}

Penelitian yang dilakukan bersifat deskriptif, dilakukan pada Oktober 2013 sampai Maret 2014. Lokasi penelitian di Bagian Rekam Medik RSUP DR. M. Djamil Padang. Cara pengambilan sampel yaitu total sampling. Data yang digunakan adalah data sekunder dari rekam medik. Data yang diperoleh dikumpulkan dan diolah secara manual dan dihitung persentasenya kemudian disajikan dalam tabel distribusi frekuensi.

\section{HASIL}

Berdasarkan penelitian yang dilakukan di Bagian Rekam Medik RSUP DR. M. Djamil ditemukan angka kejadian anemia pada kehamilan sebanyak 75 kasus $(2,2 \%)$ dari 3396 kehamilan yang dirawat di Instalasi Rawat Inap Bagian Obstetri \& Ginekologi RSUP DR. M. Djamil selama periode 1 Januari 2012 31 Desember 2012. Pada Tabel 1 menggambarkan distribusi anemia pada kehamilan berdasarkan pada 
derajat. Hasil penelitian pada Tabel 1 menunjukkan bahwa derajat anemia pada kehamilan yang tersering adalah derajat sedang, yaitu sebanyak 45 kasus $(60 \%)$.

Tabel 1. Distribusi derajat anemia pada kehamilan berdasarkan derajat anemia

\begin{tabular}{lcc}
\hline \multicolumn{1}{c}{ Derajat } & $\mathbf{f}$ & $\%$ \\
\hline Anemia ringan & 20 & 27 \\
Anemia sedang & 45 & 60 \\
Anemia berat & 10 & 13 \\
\hline \multicolumn{1}{c}{ Jumlah } & 75 & 100 \\
\hline
\end{tabular}

Keterangan: $\mathrm{f}=$ frekuensi,$\%=$ persentase kejadian.

Distribusi anemia pada kehamilan berdasarkan usia kehamilan dapat dilihat pada Tabel 2 .

Tabel 2. Distribusi anemia pada kehamilan menurut usia kehamilan dan derajat

\begin{tabular}{|c|c|c|c|c|c|c|}
\hline \multirow{2}{*}{$\begin{array}{l}\text { Usia ke } \\
\text { hamilan }\end{array}$} & \multicolumn{2}{|c|}{ Ringan } & \multicolumn{2}{|c|}{ Sedang } & \multicolumn{2}{|c|}{ Berat } \\
\hline & $f$ & $\%$ & $f$ & $\%$ & $f$ & $\%$ \\
\hline TM I & 2 & 2,7 & 5 & 6,7 & 4 & 5,3 \\
\hline TM II & 1 & 1,3 & 4 & 5,3 & 2 & 2,7 \\
\hline TM III & 17 & 23 & 36 & 48 & 4 & 5 \\
\hline Jumlah & 20 & 27 & 45 & 60 & 10 & 13 \\
\hline
\end{tabular}

Pada tabel tersebut dapat diketahui bahwa anemia pada kehamilan lebih sering terjadi pada trimester ke-3 kehamilan, yaitu sebanyak 57 kasus (76\%). Sementara itu, anemia pada kehamilan lebih sering terjadi pada multigravida, yaitu sebanyak 50 kasus $(66,6 \%)$, dapat dilihat pada Tabel 3.

Tabel 3. Distribusi anemia pada kehamilan menurut gravida

\begin{tabular}{lcc}
\hline \multicolumn{1}{c}{ Gravida } & f & $\%$ \\
\hline Primigravida & 20 & 26,7 \\
Multigravida & 50 & 66,6 \\
Grandemultigravida & 5 & 6,7 \\
\hline \multicolumn{1}{c}{ Total } & 75 & 100
\end{tabular}

Keterangan: $f=$ frekuensi, $\%=$ persentase kejadian

Hal ini sesuai dengan kepustakaan yang menjelaskan bahwa kejadian anemia pada kehamilan akan meningkat seiring dengan tingginya gravida.
Multigravida dapat menyebabkan anemia akibat cadangan besi yang berkurang akibat penggunaan untuk kehamilan sebelumnya belum cukup untuk memenuhi kebutuhan kehamilan sekarang. ${ }^{17}$ Hasil penelitian ini serupa dengan hasil penelitian di Malaysia yang melaporkan bahwa sebanyak $60 \%$ perempuan hamil yang menderita anemia adalah multigravida. ${ }^{15}$ Tetapi hasil penelitian ini tidak sejalan dengan beberapa penelitian lain yang melaporkan anemia lebih sering terjadi pada grandemultigravida. ${ }^{13}$

Tabel 4 menggambarkan kasus anemia pada kehamilan berdasarkan paritas. Dari hasil penelitian ditemukan anemia pada kehamilan paling sering terjadi pada perempuan dengan paritas satu, yaitu sebanyak 34 kasus (45,3\%). Hasil penelitian ini sejalan penelitian yang mengatakan bahwa perempuan sedikitnya dengan dua persalinan lebih sering menderita anemia. Hal ini menunjukkan bahwa sikap perempuan hamil dengan paritas satu mungkin berbeda secara signifikan dibanding dengan perempuan dengan paritas 0 , dimana perempuan dengan paritas 0 lebih memerhatikan gizinya sehingga risiko menderita anemia menjadi lebih rendah. ${ }^{12}$

Tabel 4. Distribusi anemia pada kehamilan menurut paritas

\begin{tabular}{lcc}
\hline \multicolumn{1}{c}{ Paritas } & $\mathbf{f}$ & \% \\
\hline Paritas 0 & 20 & 26,7 \\
Paritas 1-5 & 54 & 72 \\
Paritas $>\mathbf{5}$ & 1 & 1,3 \\
\hline \multicolumn{1}{c}{ Total } & 75 & 100
\end{tabular}

Keterangan: $f$ = frekuensi, $\%$ = persentase kejadian.

Pada Tabel 5 dapat dilihat mayoritas anemia pada kehamilan terjadi pada jarak kehamilan $>3$ tahun, yaitu sebanyak 25 kasus (44,7\%). Anemia mungkin terjadi akibat belum pulinnya adaptasi anatomi dan fisiologi sistem reproduksi ibu sehingga tidak siap untuk konsepsi. Tetapi, hasil penelitian ini sejalan dengan penelitian di Trinidad \& Tobago yang melaporkan bahwa jarak kehamilan tidak berpengaruh terhadap terjadinya anemia pada kehamilan. Hal ini mungkin dikarenakan gizi perempuan tersebut sudah berkurang bahkan sebelum terjadinya konsepsi. ${ }^{12}$ 
Tabel 5. Distribusi anemia pada kehamilan menurut jarak kehamilan

\begin{tabular}{lcc}
\hline \multicolumn{1}{c}{ Jarak Kehamilan } & $\mathbf{f}$ & $\mathbf{\%}$ \\
\hline$<2$ tahun & 21 & 37,5 \\
2-3 tahun & 10 & 17,8 \\
$>3$ tahun & 25 & 44,7 \\
\hline \multicolumn{1}{c}{ Total } & 56 & 100 \\
\hline
\end{tabular}

Keterangan: $f$ = frekuensi, $\%$ = persentase kejadian.

\section{PEMBAHASAN}

Organisasi kesehatan dunia, WHO pada tahun 2008 memperkirakan sebanyak 56,4 juta dari penderita anemia merupakan perempuan hamil dan paling banyak ditemukan di Asia Tenggara, yaitu sebanyak 18,1 juta. Di Raichur, India, anemia terjadi pada $88,64 \%$ kehamilan. ${ }^{17}$ Prevalensi anemia pada kehamilan di Nigeria lebih rendah, yaitu sebanyak $23,2 \%{ }^{14}$ Sementara angka kejadian anemia pada kehamilan di Ethiopia lebih rendah dibanding Nigeria, yaitu sebanyak $21,6 \% .{ }^{11}$ Prevalensi wanita hamil yang menderita anemia di Indonesia dilaporkan sebanyak $24,5 \%{ }^{3}$ Dari hasil penelitian-penelitian diatas terlihat bahwa angka kejadian anemia pada kehamilan di RSUP Dr. M. Djamil Padang jauh lebih rendah, mungkin disebabkan perbedaan daerah dilakukannya penelitian dan intervensi yang dilakukan oleh pusatpusat kesehatan, seperti antenatal care dan suplementasi besi selama kehamilan.

Hasil penelitian ini memperlihatkan derajat anemia pada kehamilan yang tersering adalah derajat sedang, yaitu sebanyak 45 kasus (60\%). Hal ini sesuai dengan teori yang menyatakan bahwa derajat anemia pada kehamilan yang paling sering terjadi adalah derajat sedang. Hal ini dikarenakan adaptasi fisiologis perempuan selama kehamilan. Hasil penelitian ini juga sejalan dengan penelitian di Pakistan yang melaporkan sebanyak $60 \%$ perempuan hamil yang anemia didiagnosis menderita anemia derajat sedang. ${ }^{13}$ Sebuah penelitian melaporkan angka kejadian yang lebih tinggi, yaitu sebanyak $90 \%$ perempuan hamil yang anemia didiagnosis menderita anemia derajat sedang. ${ }^{14}$ Hasil yang berbeda melaporkan anemia derajat ringan lebih sering terjadi. Perbedaan ini disebabkan karena berbedanya cut-off point yang digunakan untuk diagnosis anemia pada kehamilan dalam masing-masing penelitian, dimana anemia pada kehamilan didiagnosis jika kadar $\mathrm{Hb}$ perempuan hamil $<10 \mathrm{~g} / \mathrm{dL}^{12}$

Anemia pada kehamilan lebih sering terjadi pada trimester ke-3 kehamilan, yaitu sebanyak 57 kasus (76\%). Hal ini diakibatkan karena peningkatan volume plasma yang lebih tinggi dibanding peningkatan massa eritrosit mencapai titik tertinggi pada trimester ke-3 kehamilan. Selain itu, anemia juga dapat terjadi akibat peningkatan kebutuhan oksigen sesuai dengan janin yang semakin membesar. Kondisi yang sama terjadi di Pakistan, yaitu mayoritas anemia pada kehamilan terjadi pada trimester ke-3 kehamilan. $^{15}$ Hal serupa juga terjadi di Ethiopia ${ }^{1}$. Tetapi hal yang berbeda terjadi di Nigeria, dimana dilaporkan anemia pada kehamilan lebih sering terjadi pada trimester ke-2. ${ }^{14}$ Perbedaan hasil penelitian ini dapat disebabkan oleh berbagai faktor, salah satunya mungkin karena kurangnya pengetahuan ibu hamil mengenai pentingnya untuk memeriksakan kehamilan setiap trimester.

\section{SIMPULAN}

Derajat anemia pada kehamilan yang paling banyak ditemukan adalah derajat sedang dan terjadi terutama pada multigravida. Anemia pada kehamilan terbanyak ditemukan pada paritas 1 dan mayoritas terjadi pada ibu dengan jarak kehamilan $>3$ tahun.

\section{UCAPAN TERIMA KASIH}

Terimakasih kepada semua pihak atas segala pengorbanan waktu dan pikiran yang diberikan dalam pembuatan artikel ini.

\section{DAFTAR PUSTAKA}

1. Bakta IM. Hematologi klinik ringkas. Jakarta: EGC; 2006.hlm.11-6.

2. World Health Organization. Worldwide prevalence of anaemia 1993 - 2005: Geneva: WHO Global Database on Anaemia; 2008.

3. Riskesdas. Laporan nasional 2007 Badan Penelitian dan Pengembangan Kesehatan 
Departemen Kesehatan, Republik Indonesia. 2007. (diunduh 13 Juni 2013). Tersedia dari: URL: HYPERLINK http://www.depkes.go.id/downloads/ materi rakerkesnas/panel\%204/Balitbangkes.pdf.

4. Hiddayaturrahmi. Prevalensi anemia pada kehamilan dan faktor-faktor yang mempengaruhinya di Puskemas Tanjung Paku Kotamadya Solok (skripsi). Padang: Fakultas Kedokteran, Universitas Andalas, 2001.

5. Kalaivani K. Prevalence and consequences of anemia in pregnancy. Indian J Med Res. 2009; Nov;130: 627-33.

6. DeCherney $\mathrm{AH}$, Goodwin $\mathrm{T}$, Laufer N, Nathan L. Current diagnosis and treatment obstetrics \& gynecology. Edisi ke-10. United States of America : McGraw-Hill Companies. 2007.hIm.406.

7. Centers for Disease Control and Prevention. Recommendations to prevent and control iron deficiency in the United States. Morb Mortal Wkly Rep. 1998; 47:1-36.

8. Allen L. Anemia and iron deficiency: effects on pregnancy outcome. Am J Clin Nur. 2000; 71 (suppl):1280S-3S.

9. Sarwono P. IImu kebidanan. Edisi ke-4. Jakarta: PT Bina Pustaka; 2009.hlm.183-4.

10. Laflamme E. Maternal hemoglobin concentration and pregnancy outcome: a study of the effects of elevation in El Alto, Bolivia. MJM. 2010; 13(1): 47-55.
11. Alem M, Enawgaw B, Gelaw A, Kena T, Olkeba Y, Seid M. Prevalence of anemia and associated risk factors among pregnant women attending antenatal care in Azezo Health Center Gondar Town, Northwest Ethiopia. J Interdiscipl Histopathol. 2013;0(0) :1-8.

12. Uche $E O$, Jacinto $S$, Burnett $M$, Clapperton $M$, David $\mathrm{Y}$, Durga $\mathrm{S}$, et al. Anaemia in pregnancy: associations with parity, abortions and child spacing in primary healthcare clinic attendees in Trinidad and Tobago. African Health Sciences. 2010;10(1):66-70.

13. Taseer I, Awan Z, Mirbahar A, Safdar S. Anemia in pregnancy: related risk factors in underdeveloped area. Professional Med J Mar. 2011; 18(1): 1-4.

14. Buseri $\mathrm{FI}$, Jeremiah ZA, Uko EK, Usanga EA. Prevalence and risk factors of anaemia among pregnant women in Nigeria. The Open Hematology Journal. 2008; 8(2):14-9.

15. Okeke P. Anaemia in pregnancy: is it a persisting public health problem in Porto Novo-Cape Verde? Res. J. Med Sci. 2011;5(4):193-9.

16. Jamaiyah $H$, Das A, Teck L, Won Sun, Nordin Mohd, Rampal S, et al. Anemia in pregnancy in Malaysia: a cross sectional survey. Asia Pac J Clin Nutr. 2007;16(3):527-36.

17. Vijaynath, Jitendra, Patel A, Patil RS. Prevalence of anemia in pregnancy. The Indian Journals In press. 2013. 